Ks. Piotr Kot

\title{
PIERWSZY LIST ŚW. JANA JAKO ŚWIADECTWO TEOLOGICZNE \\ O HISTORII ZBAWIENIA REALIZUJĄCEJ SIE W JEZUSIE CHRYSTUSIE
}

\section{The First Letter of John as a Theological Testimony about the Salvation History Accomplished in Jesus Christ}

\begin{abstract}
Reading the First Epistle of John, one is led to inquire about the nature of the testimony that the author of the letter offers to the Christian community in crisis. Is this a testimony based on an inculcated doctrine or does it originate in the historical experience of the author? This is, in essence, a question regarding the authority of the teaching presented in the letter. The vocabulary employed in the letter, particularly in its prologue, permits us to define the testimony under consideration as a theological testimony. It does not consist of a faithful recalling of memories of past historical events only. Indeed, the author of 1 John does not refer directly to any words or deeds of an earthly Jesus. Rather, the testimony consists in treating the historical facts as a "source of the present time." This testimony enjoys strong authority because it arises from two sources: from an account of the eye-witness of the paschal life of Jesus Christ and also from reflection upon the existential outcomes of this historical and salvific event in relation to the current needs of the community.
\end{abstract}


Keywords: Testimony, First Letter of John, Prologue, Johannine Work

Streszczenie: Lektura Pierwszego Listu św. Jana rodzi pytanie o naturę świadectwa, które autor pisma składa wobec wspólnoty chrześcijańskiej przeżywającej wewnętrzny kryzys. Czy jest to świadectwo oparte na wyuczonej doktrynie, czy też wyrasta $\mathrm{z}$ doświadczenia historycznego autora? Jest to w gruncie rzeczy pytanie o autorytet prezentowanej nauki. Słownictwo zastosowane zwłaszcza w prologu Listu pozwala określić go jako świadectwo teologiczne. Nie polega ono jedynie na wiernym przywoływaniu z pamięci przeszłych wydarzeń historycznych, gdyż w $1 \mathrm{~J}$ autor nie odnosi się wprost do słów i czynów ziemskiego Jezusa. Jest ono raczej traktowaniem zaistniałych faktów jako ,źródła teraźniejszości”. Świadectwo to posiada silny autorytet, ponieważ wyrasta z dwóch źródeł: relacji naocznego świadka paschalnego życia Jezusa Chrystusa oraz refleksji nad egzystencjalnymi konsekwencjami tego historiozbawczego wydarzenia w obliczu aktualnych potrzeb wspólnoty.

Słowa kluczowe: świadectwo, Pierwszy List św. Jana, prolog, dzieło Janowe

Pierwszy List św. Jana różni się od czwartej Ewangelii nie tylko pod względem koncepcji teologicznej i literackiej pisma, ale również pod względem znaczenia niektórych pojęć ${ }^{1}$. Należą do nich czasownik martyreō oraz derywat rzeczownikowy martyria. Jaką funkcję spełniają powyż-

${ }^{1}$ Przede wszystkim czytelnicy czwartej Ewangelii i Pierwszego Listu św. Jana zauważają zasadniczą różnicę w odniesieniu do literackiego sposobu prezentacji treści w obu pismach. Istnieje dyskusja co do określenia gatunku $1 \mathrm{~J}$ jako listu (zob. Klauck, Lettere di Giovanni, 4548). Istotne zdanie na ten temat prezentuje S. Stowers. Ustosunkowując się do koncepcji uczonych, którzy wskazują w badaniach na odejście autora Pierwszego Listu św. Jana od klasycznej formy listu, S. Stowers wskazuje na liczne odstępstwa od „czystej formy”. Podkreśla on, że w starożytności listy miały przede wszystkim charakter funkcjonalny i określały zadania, które mieli spełnić adresaci. To z kolei wymuszało pragmatyzm w strukturze i formie. W takim kontekście S. Stowers określa 1 J jako „list parenetyczny”. Zob. Stowers, Letter Writing, 96. 
sze terminy w realizacji planu tematycznego Pierwszego Listu św. Jana? Kto jest podmiotem i adresatem działania wyrażonego przez czasownik martyreō? Jakie cechy semantyczne, charakterystyczne dla $1 \mathrm{~J}$, obejmuje rzeczownik martyria? Te pytania są istotne nie tylko dlatego, że czytelnicy tzw. dzieła Janowego z łatwością dostrzegają różnice $\mathrm{w}$ pismach powstałych na przestrzeni wielu lat w tzw. szkole Janowej, ale również z tego powodu, że $1 \mathrm{~J}$ jest odpowiedzią na egzystencjalne potrzeby określonej wspólnoty Kościoła, do której w większości należały osoby niemające możliwości poznania historycznego Jezusa².

\section{Martyreō i martyria W Pierwszym Liście ŚW. JANA}

W badaniach, które w odniesieniu do terminu martyria przeprowadził P. Podeszwa ${ }^{3}$, wskazane są dwie możliwości wyprowadzenia jego etymologii. Jedna $\mathrm{z}$ nich wiąże go $\mathrm{z}$ pojęciem martys i indoeuropejskim rdzeniem smer/mer, który oznacza „mieć w pamięci, pamiętać, przypominać sobie”. Słowo martys mogłoby oznaczać ,tego, kto ma coś w pamięci, przypomina sobie, ze swoich wspomnień czerpie poznanie jakiejś rzeczywistości i dlatego może przekazać wiadomości na jej temat, staje się zatem jej

${ }^{2}$ Interesująca jest nie tylko wzajemna relacja J i $1 \mathrm{~J}$, ale też autorów tych utworów i ich odbiorców. W.E. Sproston uzasadnia tezę, że czwarta Ewangelia i Pierwszy List św. Jana są w ścisłej zależności źródłowej (korzystają z tego samego świadectwa), ale też autorzy piszą swe dzieła dla wspólnot charakteryzujących się znajomością tego źródła. Tym, co stanowi zasadniczą różnicę, jest odmienne Sitz im Leben (Ewangelia kontrowersje z judaizmem końca I wieku; $1 \mathrm{~J}$ - problem chrystologiczny i rozłam we wnętrzu wspólnoty chrześcijańskiej). Niemniej w pełni uprawnione są badania komparatywne, zwłaszcza leksykalne, choć nie można automatycznie aplikować tego samego znaczenia teologicznego do pojęć obecnych w obu utworach. Zob. Sproston, „Witness”, 43-65. Por. Jaromin, „Chrystologia”, 62.

${ }^{3}$ Podeszwa, Paschalna. 
świadkiem"4. Termin martyria oznaczałby zatem przekaz wiadomości na temat jakiejś poznanej i przypomnianej rzeczywistości. Druga możliwość wyprowadzenia etymologii rzeczownika martyria to utworzenie go od czasownika martyreō w procesie dodania do rdzenia końcówki -ía, która „wskazuje na rzeczownik abstrakcyjny, używany często jako nomen actionis dla wyrażenia dawania świadectwa oraz samego aktu świadectwa jako takiego"s. Obie ścieżki badawcze dają bardzo ogólną podstawę dla szczegółowych badań nad polem semantycznym rzeczownika martyria $\mathrm{w} 1 \mathrm{~J}$, które mieści się $\mathrm{w}$ ramach ,pamięci wynikającej z doświadczenia i refleksji, to znaczy odniesienia podmiotu do rzeczywistości przeżytej i zweryfikowanej (zapamiętanej), która nie może pozostać zapomniana. [...] W ten sposób świadectwo ma swoje korzenie w doświadczeniu”. Wskazanie na nierozłączność świadectwa $\mathrm{z}$ doświadczeniem jest bardzo istotne dla czytelników Pierwszego Listu św. Jana, niezależnie od tego, w jakim czasie konfrontują się oni z przesłaniem pisma, ponieważ tylko w takim przypadku utwór ten posiada autorytet w Kościele. Na czym zatem polega owo „doświadczenie” w odniesieniu do Pierwszego Listu św. Jana? Czy zawiera się w nim pamięć naocznych świadków, czy też kolejnej generacji uczniów? Jeśli nie byłoby to świadectwo naocznych świadków, to co gwarantuje jego ponadczasowe i powszechne przesłanie?

\subsection{Natura świadectwa Pierwszego Listu św. Jana}

Czasownik martyreō występuje w $1 \mathrm{~J}$ sześciokrotnie w różnych formach. W 1,2 i 4,14 pojawia się on w trybie oznajmującym czasu teraźniejszego ( 1 os., 1. mn. - martyroumen), w 5,9.10 w trybie oznajmującym czasu perfectum

${ }^{4}$ Jest to definicja, którą P. Podeszwa (Podeszwa, Paschalna, 64) podaje za H. Strathmannem (Strathmann, ,martys ktl.”, k. 1274).

${ }^{5}$ Podeszwa, Paschalna, 63.

${ }^{6}$ Podeszwa, Paschalna, 64. 
(3. os., 1. poj. - memartyrēken), natomiast w pozostałych dwóch miejscach, a więc w 5,6.7, jako imiesłów czasu teraźniejszego (5,6 - martyroun; 5,7 - martyrountes). W odniesieniu do tych form trzeba zauważyć fakt, że posiadają one również odmienne podmioty działania: w 1,2 i 4,14 podmiot działający nie jest doprecyzowany, w 5,9.10 podmiotem działania jest Bóg Ojciec, natomiast formy imiesłowowe odnoszą się do Ducha $(5,6)$ oraz do Ducha, wody i krwi $(5,7)$. W kontekście tak zróżnicowanego zastosowania czasownika martyreō, dodatkowo w specyficznym kontekście powstania Pierwszego Listu św. Jana w jego relacji do czwartej Ewangelii, zastanawiające jest przesłanie, które autor pisma przekazuje adresatom.

Mówiąc o autorze pisma, trzeba koniecznie zaznaczyć, że w odniesieniu do Pierwszego Listu św. Jana ciągle trwa dyskusja na temat tego, kto stoi u genezy powstania utworu i kto je ostatecznie redagowal ${ }^{7}$. Podstawowe kierunki badawcze bardzo syntetycznie prezentuje na polu biblistyki polskiej F. Mickiewicz ${ }^{8}$ a wśród badaczy obcojęzycznych R.E. Brown ${ }^{9}$, H.-J. Klauck ${ }^{10}$ czy też J. Painter ${ }^{11}$. Sama kwestia autorstwa lub redakcji bardzo ściśle łączy się z zagadnieniem świadectwa, stąd niezwykle istotne wydają się badania nad znaczeniem poszczególnych form czasownika martyre o $\mathrm{w} 1 \mathrm{~J}$ oraz kontekstualnego rozumienia terminu martyria.

W odniesieniu do czasownika martyreō na pierwszy plan wysuwa się dwukrotnie zastosowana w $1 \mathrm{~J}$ forma martyroumen. Po raz pierwszy pojawia się ona w prologu, co bardzo mocno uwydatnia specyficzne znaczenie opisanego przez ten czasownik działania. Prolog (1 J 1,1-4),

${ }^{7}$ Ponieważ dyskusja na ten temat nie jest zamknięta, w niniejszym artykule będziemy posługiwali się kategorią ,,autor" w odniesieniu do domniemanego ostatecznego redaktora Pierwszego Listu św. Jana, niezależnie od tego, czy była to jedna osoba, czy grupa osób wewnątrz tzw. szkoły Janowej.

${ }^{8}$ Mickiewicz, Świadkowie, 258-260.

${ }^{9}$ Brown, The Epistles, 15-35.

${ }^{10}$ Klauck, Lettere, 59-65.

${ }^{11}$ Painter, First, 44-51, 58-77. 
który R.E. Brown określa mianem „Prologu teologicznego" ${ }^{12}$, składa się z dwóch zdań, z których pierwsze jest wielokrotnie złożone, a przez to niełatwe do thumaczenia. Tytuł nadany przez R.E. Browna tym kilku wersetom wskazuje, że prezentują one podstawowe tematy, które zostaną rozwinięte $w$ następnych częściach pisma. Tak więc $\mathrm{w}$ pierwszych trzech wersetach $1 \mathrm{~J}$ autor opisuje w pierwszej osobie liczby mnogiej doświadczenia zmysłowe, które stanowią podstawę autentyczności i gwarancję autorytetu świadectwa „w odniesieniu do Słowa Życia”:

To, co było (ēn) od początku, co słyszeliśmy (akēkoamen), co widzieliśmy (heōrakamen) naszymi oczami; to, co zobaczyliśmy (etheasametha) i [czego] dotknęły (epsēlafêsan) nasze ręce w odniesieniu do Słowa Życia (peri tou logou tēs $d z \bar{o} \bar{e} s$ ) - gdyż Życie zostało objawione (efanerōthē), i widzieliśmy (heōrakamen) i świadczymy (martyroumen) i [na skutek tego] proklamujemy (apangellomen) wam Życie wieczne, które było u Ojca, a nam zostało objawione (efanerōthēe - to, co widzieliśmy (heōrakamen) i słyszeliśmy (akēkoamen), proklamujemy (apangellomen) również wam, abyście i wy mieli z nami [w tym, co należy do nas] (meth' hemōn) współudział (koinonía), a [jest to] nasz współudział [w tym, co jest wspólne] pomiędzy (meta) Ojcem i Jego Synem, Jezusem Chrystusem (1 J 1,1-3).

Nagromadzone w powyższym tekście czasowniki, zastosowane $\mathrm{w}$ różnych formach stanowią warunek sine qua non w odniesieniu do mocy oraz autorytetu składanego świadectwa. Przyglądając się im, należy zastosować podwójne kryterium interpretacyjne: morfologiczne oraz semantyczne. Z punktu widzenia morfologicznego należy wyodrębnić cztery grupy: (1) czasowniki w aoryście (etheasametha, epsēlafēsan) (2) czasowniki w czasie perfectum (akēkoamen, heōrakamen); (3) czasowniki w czasie teraźniejszym (martyroumen, apangellomen); (4) czasowniki w stronie biernej (efanerōthē). Z punktu widze-

${ }^{12}$ Brown, The Epistles, 174. R.E. Brown dodaje, że prolog w $1 \mathrm{~J}$ jest celowym odzwierciedleniem (deliberate reflection) Prologu czwartej Ewangelii, przez co odbiorcy pisma automatycznie łączyli $1 \mathrm{~J}$ z J. 
nia teologicznego należy wyodrębnić grupę czasowników opisujących widzenie, ogląd jakiejś rzeczy (heōrakamen, etheasametha, efanerōthē). W kontekście tak bogatego aparatu językowego rodzi się pytanie o to, na jakiej podstawie autor $1 \mathrm{~J}$ nadaje autorytatywną moc swojemu świadectwu oraz czy to, na czym jest ono osadzone, ma charakter empiryczny, podchodzący pod zmysły, czy też jest jakimś szerzej rozumianym procesem, którego punkt wyjścia stanowi doświadczenie zmysłowe, zakotwiczone w konkretnej historii, a następnie odpowiednio ukształtowane na drodze refleksji teologicznej? Jest to $\mathrm{w}$ gruncie rzeczy pytanie o naturę świadectwa.

Pierwsze kryterium interpretacyjne obejmuje różne pod względem czasu i strony formy czasownikowe. W odniesieniu do czasowników odnoszących się do postrzegania wzrokowego bardzo ważne są pojawiające się $\mathrm{w}$ prologu, ale istotne dla całego dzieła Janowego, czasowniki hora $\bar{o}$ oraz theaomai. Pierwszy z nich (hora $\overline{\text { ) }}$ jest patrzeniem kontemplacyjnym, przenikającym do głębi istotę rzeczy, a więc określa bardzo często widzenie czegoś w jego globalnym znaczeniu na skutek otrzymania daru poznania tajemnicy (zob. J 1,39; 6,14; 9,37; 20,8) ${ }^{13}$. W dziele Janowym podobne znaczenie posiada theaomai, który występuje sześciokrotnie w czwartej Ewangelii (J 1,14.32.38; 4,35; 6,5; 11,45) i trzykrotnie w Pierwszym Liście św. Jana (1 J 1,1; 4,12.14). Podstawowe znaczenie tego czasownika to ,uważne wpatrywanie się w przedmiot, który znajduje się przed oczami, lub wnikanie w głębszy sens wydarzenia, którego jest się świadkiem"'14. Czasownik ten w wielu miejscach należałoby thumaczyć opisowo jako „widzenie od wewnątrz”, „spojrzenie oświetlone darem poznania na skutek działania Ducha Parakleta" (zob. J 1,14.32; 11,45). Jak podkreśla W. Michaelis, takie spojrzenie wiary nie wyklucza bynajmniej bycia naocznym świadkiem wydarzenia historycznego ${ }^{15}$. Mocno uwypukla

\footnotetext{
${ }^{13}$ Por. Witczyk, Kościót, 330; Sikora, Zobaczyt i uwierzyt, 124-125.

${ }^{14}$ Witczyk, Kościót, 160.

${ }^{15}$ Michaelis, „horaō, theaomai, ecc.”, 345.
} 
ten aspekt H. Witczyk, który w odniesieniu do „oglądania chwały Wcielonego Słowa” (J 1,14), interpretuje zastosowany $\mathrm{w}$ tym zwrocie czasownik theaomai w następujący sposób: „W przypadku patrzenia uczniów na Jezusa czasownik ten opisuje proces przechodzenia od spostrzegania rzeczywistości zewnętrznej, Jego ludzkiej kondycji, do oglądania zawartego w niej misterium. W wersecie $1,14 \mathrm{c}$ oznacza on, że naoczni świadkowie ziemskiego życia Jezusa (wskazuje na to forma aorystu) od wizji zewnętrznej stopniowo przechodzili do wizji wiary [...]"16.

Obok bogactwa znaczeniowego czasowników określających sposób widzenia rzeczy na szczególną uwagę zasługuje zastosowanie formy perfectum, tak w odniesieniu do horaō, jak i dla opisania wrażeń słuchowych i wzrokowych w odniesieniu do przedmiotu świadectwa. W tym kontekście istotne wydają się spostrzeżenia T. Griffith, który zauważa, że w $1 \mathrm{~J}$ o autentyczności świadectwa sygnalizowanego w prologu może świadczyć stosowana w innych miejscach utworu forma perfectum czasownika oida (zob. 1 J 3,2.14; 5,19.20). Wiedza (oidamen) autora na temat konkretnego działania Boga w historii, do której tak często się odwołuje i której nadaje kształt świadectwa (martyroumen), jest skutkiem doświadczenia opisanego w prologu. T. Griffith, analizując wzajemne powiązanie oidamen z akēkoamen i heōrakamen w Pierwszym Liście św. Jana, nawiązuje do ich bliskiego związku z dwoma tekstami czwartej Ewangelii: J 3,11 oraz 4,42. T. Griffith zastanawia się nad tym, jaki aspekt czasowy wyrażają te trzy formy czasownikowe, to znaczy, czy idąc po linii klasycznej wykładni językowej, należy mówić o wydarzeniu z przeszłości, którego skutki trwają w teraźniejszości. Posiłkując się badaniami B.M. Fanninga ${ }^{17}$ oraz S. Portera ${ }^{18}$, T. Griffith określa formę oidamen jako ,perfectum co do formy, ale nie co do znaczenia" ${ }^{19}$. Znaczeniowo oidamen

\footnotetext{
16 Witczyk, Kościót, 161.

17 Fanning, Verbal Aspect.

18 Porter, Verbal Aspect.

${ }^{19}$ Griffith, Keep Yourselves, 104.
} 
wskazuje na wiedzę trwale nabytą, odpowiednio uzasadnioną i przechowywaną $\mathrm{w}$ pamięci. Jednak według niego formy czasownikowe akēkoamen i heōrakamen różnią się od oidamen, gdyż należą do kompozycji otwartej pisma ${ }^{20}$, co oznacza, że określają punt wyjścia, niejako źródło wiedzy, a przez sam fakt ich zakorzenienia w wydarzeniu historycznym dają odbiorcom gwarancję wiarygodności przekazywanych prawd ${ }^{21}$. Przywołane powyżej dwa teksty z czwartej Ewangelii, tj. J 3,11 oraz 4,42, które należą do tej samej tradycji teologiczno-literackiej co $1 \mathrm{~J}$, ewidentnie dokumentują wniosek T. Griffith, że formy perfectum akēkoamen i heōrakamen są stosowane w tradycji Janowej w znaczeniu emfatycznym, to znaczy, że odnoszą się do realnego doświadczenia przechowywanego w pamięci i je eksponują, przez co stają się gwarantem autentyczności przekazywanego świadectwa (zob. też J 20,25) ${ }^{22}$. Powyższe wnioski należałoby rozwinać na podstawie najnowszych badań lingwistycznych C.R. Campbella oraz A.D. Nasellego. Ten ostatni w jednym ze swoich przyczynków podkreśla, że współcześni egzegeci pism NT nieco inaczej podchodzą do zagadnienia aspektu wydarzenia określonego przez odpowiednią formę czasownika ${ }^{23}$. Obecnie uczeni bardzo mocno koncentrują się na precyzyjnym określeniu stosunku autora lub narratora do wydarzenia jako takiego oraz na opisaniu zamierzonych działań redaktora, które ten podejmuje wobec tekstu świadectwa najczęściej z przesłanek pragmatycznych (egzystencjalnych). Próbując odtworzyć najgłębsze intencje autora tekstu, należy najpierw odpowiednio opisać formy, które nadał on czasownikom, chcąc przez to wyrazić aspekt jakiegoś działania lub wydarzenia (dokonany lub niedokonany) oraz czas (dalsza lub bliższa odległość) ${ }^{24}$. W tym kontekście do ciekawych wniosków dochodzi C.R. Campbell. Przyporządkowuje

${ }^{20}$ B.M. Fanning określa taką kompozycję jako ,reflective and discursive style" (Fanning, Verbal Aspect, 297).

${ }^{21}$ Griffith, Keep Yourselves, 105.

${ }^{22}$ Griffith, Keep Yourselves, 105.

${ }^{23}$ Naselli, ,A Brief Introduction”, 17-28.

${ }^{24}$ Naselli, „A Brief Introduction”, 28. 
on formom czasownikowym tylko dwa aspekty: dokonany (sposób widzenia, w którym wydarzenie jest widziane niejako z zewnątrz) i niedokonany (wydarzenie ogląda się od wewnątrz), ale określa wobec nich pięć kategorii przestrzennych ${ }^{25}$, które mogą oznaczać odległość logiczną, narracyjną, ale też czasową (od "największej bliskości” poprzez „największe oddalenie” do nieokreślonego). Według niego perfectum wyraża aspekt niedokonany w największej bliskości czasowo-przestrzennej ${ }^{26}$. To oznacza, że w pełni uzasadnione jest twierdzenie, iż w przypadku form akēkoamen i heōrakamen zastosowanych w prologu $1 \mathrm{~J}$ autor odwołuje się do doświadczenia „z pierwszej ręki”, przez co z kolei może określić siebie jako świadka wydarzeń zbawczych dokonanych w Jezusie Chrystusie ${ }^{27}$.

\subsection{Martyroumen - „my” to znaczy kto?}

Spośród siedemnastu form czasownikowych występujących w początkowym fragmencie $1 \mathrm{~J} \mathrm{1,1-4} \mathrm{aż}$ dziesięć występuje w 1. os. mn. Zatem forma „my” jest dominująca. Zresztą dominuje ona w całym piśmie, choć zastanawiające jest, że już kilka wersetów za prologiem (1 J 2,1) autor wypowiada się w pierwszej osobie liczby pojedynczej. Mimo że taka zmiana nie jest zbyt częsta (zob. 2,1.7-8.12-14.21.26; 5,13.16), jest to czynnik, który mocno komplikuje kwestię ustalenia podmiotu, a co się z tym wiąże - również natury świadectwa. Spośród różnych hipotez związanych z precyzyjnym określeniem, kto ukrywa się za formą „my”, warto wskazać najczęściej wysuwane przez uczonych, które bardzo syntetycznie przedstawia H.-J. Klauck ${ }^{28}$.

${ }^{25} \mathrm{~W}$ języku angielskim autor używa trudnego do thumaczenia terminu „spatial”. Campbell, Verbal Aspect, 11.

${ }^{26}$ Campbell, Verbal Aspect, 244.

${ }^{27}$ Formy perfectum oznaczają bliskość doświadczenia, ale nie są jednoznaczne z tym, że autor określa siebie jako bezpośredniego uczestnika wydarzeń historycznych: „To, co naprawdę/rzeczywiście widzimy, co naprawdę/rzeczywiście dotykają nasze ręce”.

${ }^{28}$ Klauck, Lettere, 91-92. 
Pierwsza z nich określa podmiot „my” na sposób kolektywny. Mieści się w nim autor pisma oraz członkowie wspólnoty, którzy wyznają mesjańską godność Jezusa z Nazaretu. W takim rozumieniu uprawnione byłoby dochodzenie do głosu w niektórych momentach utworu ,ja" autora. Problemem pozostaje jednak sam prolog, pisany intencjonalnie według dialektyki autor - adresaci (zob. 1,4 ), oraz tekst $1 \mathrm{~J} 4,14$, w którym następuje przejście od „my” w rozumieniu kolektywnym ,autor - wspólnota” do „my” autora jako takiego.

Kolejna hipoteza łączy podmiot „my” z samym autorem pisma, a liczbę mnogą traktuje jako figurę stylistyczną w pewnym sensie analogiczną do pluralis maiestatis. W języku greckim taki zabieg literacki był dobrze znany. Dodatkowo, posługujący się nim autorzy często w swoich utworach przechodzili od liczby mnogiej do liczby pojedynczej i odwrotnie. W przypadku Pierwszego Listu św. Jana posługiwanie się przez autora formą „my” miałoby na celu nadanie własnemu świadectwu mocy autorytetu, wypływającego z racji przynależności do określonej wspólnoty, stojącej za autorem. W tym kontekście niezrozumiałe jest jednak pojawienie się w prologu dialogu pomiędzy „my” autora $\mathrm{i}$ „wy” wspólnoty.

Powyższa propozycja została rozwinięta przez H.-J. Klaucka. Uczony ten łączy autorstwo $1 \mathrm{~J}$ ze wspólnotą, która różni się od ,ja” tego, kto pisze/przekazuje pierwszą relację oraz od "wy” odbiorców. Jest to sytuacja analogiczna do tych miejsc w czwartej Ewangelii, w których pojawia się dodatkowy podmiot, przytaczający i interpretujący z pewnego dystansu świadectwo naocznego świadka, do którego miał bezpośredni dostęp (zob. np. J 21,24 lub 19,35). W tym wypadku ,my” podmiotu w Pierwszym Liście św. Jana odnosiłoby się do tzw. szkoły Janowej, a „wy” adresatów obejmowałoby tych, którzy na różnych etapach funkcjonowania wspólnot byliby odpowiedzialni za przekazywanie zdrowej nauki, opierającej się na dziele Janowym, a więc prezbiterów, teologów i katechetów. Ta teoria wydaje się najbardziej przekonująca, niemniej jednak nie jest wolna od kolejnych pytań. Skoro 
bowiem u podstaw świadectwa obecnego w Pierwszym Liście św. Jana znajduje się doświadczenie ,szkoły Janowej”, to czy ma ono wartość historyczną, czy jedynie symboliczną? Kto tworzy „szkołę Janową” odpowiedzialną za przekaz świadectwa o Jezusie Chrystusie i Jego dziele zbawczym?

H.-J. Klauck, odnosząc się do zagadnienia istnienia i funkcjonowania tzw. szkoły Janowej w odniesieniu do Pierwszego Listu św. Jana w jego relacji do czwartej Ewangelii podkreśla, że przypisywanie ostatecznych redakcji obu pism tej samej grupie, funkcjonującej wewnątrz „szkoły Janowej”, jest wątpliwe ${ }^{29}$. Raczej na proces ich kształtowania należy patrzeć rozdzielnie, a „szkołę Janową" trzeba traktować jako grupę dosyć szeroką, choć zakorzenioną w historycznym świadectwie apostoła Jana. Więcej światła na to zagadnienie rzuca A. Dalbesio ${ }^{30}$. Według niego w Pierwszym Liście św. Jana forma „my” obejmuje dwa podmioty: apostoła Jana, jako naocznego świadka Jezusa Chrystusa, oraz uczniów apostoła, którzy, opierając się na jego autorytecie, wiernie przekazali otrzymane świadectwo ${ }^{31}$. Przekaz ten jednak nie ograniczał się do mechanicznego odtwarzania przejętego przesłania, ale został wzbogacony o teologiczną interpretację faktów w kontekście egzystencjalnym. Taki proces teologicznego kształtowania przekazu apostolskiego, który można określić mianem pracy redakcyjnej, jest uprawomocniony przez samego Jezusa. W relacji z Ostatniej Wieczerzy św. Jan przytacza słowa Mistrza, który zwraca się do uczniów: „Gdy przyjdzie Paraklet, którego Ja wam poślę od Ojca [...] On będzie świadczył o Mnie. Ale wy też świadczy-

${ }^{29}$ Klauck, Lettere, 65.

${ }^{30}$ Dalbesio, Quello che abbiamo, 114-16.

${ }^{31} \mathrm{~S}$. Mędala prezentuje podobne stanowisko w odniesieniu do J 3,11: „Przejście od liczby pojedynczej do mnogiej oznacza, że świadectwo Jezusa zostaje podjęte w świecie przez świadectwo Ducha-Parakleta i uczniów, wśród których występuje ewangelista $(15,16-27)$. W czwartej Ewangelii mamy świadectwo wspólnotowe i równocześnie zindywidualizowane świadectwo umiłowanego ucznia Jezusa (por. 19,35; 21,24)". Mędala, Ewangelia, 420. 
cie, bo jesteście ze Mną od początku" (J 15,26-27). Popaschalne świadectwo uczniów od samego początku było połączone z refleksją aktualizującą. Dowodem tego są wzmianki w czwartej Ewangelii, w których uczniowie bardzo wyraźnie wskazują na fakt, że w przekazie wiary nie ograniczają się jedynie do relacjonowania wydarzeń z życia Jezusa (zob. J 2,13-22; 12,12-16). Szczególnie znamienna w tym kontekście jest perykopa o wyrzuceniu sprzedawców ze Świątyni Jerozolimskiej (J 2,13-22). Redaktor czwartej Ewangelii przekazuje w niej dojrzałą interpretację wydarzenia historycznego, na które patrzy już z punktu widzenia Paschy Jezusa ${ }^{32}$. Ponadto pisze on swoje świadectwo w kontekście sporów z Synagogą, w których odwoływano się do niezrozumiałego dla Zydów zachowania Jezusa z Nazaretu ${ }^{33}$. Być może chciano przypisać Mu miano rewolucjonisty podburzającego tłum, a tym samym na Niego i Jego uczniów przerzucić odpowiedzialność za wypadki, które doprowadziły do zburzenia świątyni w $70 \mathrm{r}^{34}$ Redaktor Ewangelii, który niekoniecznie musiał być naocznym świadkiem wydarzeń opisanych w J 2,13-22 $2^{35}$, miał przeświadczenie, że uczestnicząc w darze Ducha Parakleta, ma wewnątrz wspólnoty wiary prawo do interpretacji i aktualizacji historycznych faktów zre-

${ }^{32}$ Beutler, Das Johannesevangelium, 131.

${ }^{33}$ Por. Mędala, Ewangelia, 385.

${ }^{34}$ M.S. Wróbel zauważa, że „w słowach Jezusa o «zburzeniu» świątyni [J 2,19 - dop. autor] można zobaczyć aluzję do 70 r. po Chr., kiedy to świątynia została zburzona przez Rzymian” oraz, że „kontrowersje prawno-rytualne, które dostrzegamy na kartach czwartej Ewangelii, świadczą, że Janowi Ioudaioi mają konkretne twarze (aspekt historyczny) i konkretne problemy spowodowane rozłamem wspólnoty z judaizmem (aspekt socjologiczny)" (Wróbel, Antyjudaizm, 151, 242). J.J. Scott dowodzi, że w tekstach ewangelicznych relacjonujących stosunek Jezusa do świątyni i obowiązki kultowe redaktor Ewangelii odzwierciedla stanowisko niektórych zhellenizowanych kręgów wewnątrz judaizmu, które funkcjonowały po 70 r. po Chr. Zob. Scott, Jewish Backgrounds, 154.

${ }^{35}$ Zob. więcej na ten temat: Mędala, Ewangelia, 122-134, 148-149. 
lacjonowanych, a może nawet spisanych, przez apostoła Jana - naocznego świadka życia Jezusa z Nazaretu ${ }^{36}$.

\section{Treść ŚWiadectwa}

W Pierwszym Liście św. Jana treścią świadectwa jest Jezus z Nazaretu, Syn Boży, namaszczony przez Ojca (= Chrystus) i posłany do świata jako Zbawiciel i dawca życia. Autor dzieła, pisząc o świadectwie Boga o Jezusie Chrystusie, najczęściej posługuje się formą rzeczownikową martyria (1 J 5,9[x3].10[x2].11). Świadectwo przyjmuje w ten sposób postać formuły wiary, określonej doktryny. W takim przypadku pewną niedogodnością, z punktu widzenia adresata $1 \mathrm{~J}$, staje się niemożność określenia osobistej relacji autora pisma w stosunku do Tego, o kim jest wydawane świadectwo. Co prawda dzięki temu otrzymuje ono boski autorytet, ale zostaje ograniczona jego weryfikacja historyczna.

Dla przeciwwagi autor $1 \mathrm{~J}$ w odniesieniu do własnego świadectwa używa form czasownikowych, które obejmują podmiot działający i treść (przedmiot), a ponadto samo działanie jest osadzone w konkretnych, bardzo istotnych okolicznościach, opisanych za pomocą szerokiej gamy czasowników (zob. 1 J 1,1-3). Treścią świadectwa, które autor przekazuje adresatom, jest, „życie wieczne, które było u Ojca”, a „zostało objawione” świadczącym o nim (por. $1 \mathrm{~J}$ 1,2). Warto zauważyć, że ta bezpośrednia wykładnia znajduje się niejako w centrum modelu orbitalnego. Wokół niej pojawiają się czasowniki widzenia, słyszenia i dotykania, w których podmiotem działającym jest ta sama postać co w przypadku martyroumen. Zmienia się sposób określenia przedmiotu doznań i działań, które na-

${ }^{36}$ S. Mędala (Ewangelia, 397) podkreśla, że w odniesieniu do tych interpretacji nie chodzi o dodawanie czegoś nowego, ale o ,proklamowanie zbawczego działania Boga w Chrystusie zapowiedzianym w Starym Testamencie. Duch Paraklet daje poznać uczniom zbawczy, teologiczny sens oczyszczenia świątyni i wypowiedzi Jezusa". 
stępnie stają się źródłem i treścią świadectwa. Opis tego przedmiotu jest bardzo enigmatyczny i ogranicza się do formy neutrum zaimka względnego ho (,to”; „to, co”), w dwóch miejscach doprecyzowanego przez wyrażenia przyimkowe: ho èn ap' archēs $(1,1)$ oraz peri tou logou tēs $d z \bar{o} \bar{e} s(1,1)$. Nie jest łatwo określić, co dokładnie wyraża zaimek względny ho. Pewne jest jedynie, że odnosi się on do tajemnicy zbawczego działania Boga w Jezusie Chrystusie - Logosie, Słowie, które jest Życiem wiecznym $^{37}$. Na takie znaczenie zaimka wskazuje wyrażenie przyimkowe ap'archēs. Pomimo trudności z interpretacją rzeczownika arche można $\mathrm{z}$ dużym prawdopodobieństwem przyjąć, że kryje on w sobie świadectwo uczniów i obejmuje okres od inauguracji działalności publicznej Jezusa Chrystusa $^{38}$ aż do Jego wstąpienia do nieba ${ }^{39}$. Równie niełatwe do wyjaśnienia jest drugie wyrażenie przyimkowe peri tou logou tès $d z \bar{o} \bar{e} s^{40}$. Z jednej strony - zastanawia znaczenie przyimka peri, a z drugiej strony - funkcja

${ }^{37}$ J. Painter (First, 120) wyraża przypuszczenie, że autor $1 \mathrm{~J}$ móg1 wybrać formę neutrum zaimka ho dla oznaczenia, że nie ma na myśli osoby, ale „wiadomość”. Zaprzecza temu zdecydowanie H.-J. Klauck (Lettere, 74), który wskazuje, że w czwartej Ewangelii jest wiele miejsc, w których forma neutrum zaimka względnego ho odnosi się do osoby (zob. J 4,22; 6,37).

${ }^{38}$ Dla każdego ewangelisty będzie to nieco inny moment (np. kontekst chrztu w Jordanie - Mk 1,1 nn; Łk 3,23; lub według Jana znak w Kanie Galilejskiej - J 2,11). Więcej na ten temat zob. Brown, The Epistles, 157.

${ }^{39}$ Trwa ciągła dyskusja teologów na temat znaczenia wyrażenia ho èn ap' archēs w $1 \mathrm{~J}$ 1,1. Zob. Brown, The Epistles, 155-158. Bardzo syntetycznie zagadnienie to prezentuje Mickiewicz, Świadkowie, 261-262.

${ }^{40}$ Istnieją różne możliwości tłumaczenia tego wyrażenia, a dodatkową trudność wprowadza znaczenie rzeczownika logos, zwłaszcza w jego relacji do Prologu czwartej Ewangelii. G. Passarella ( $\mathrm{La}$ dinamica, 96-97) w swoim obszernym opracowaniu tego zagadnienia prezentuje bardzo dobrą tezę w odniesieniu do interpretacji logos $\mathrm{w} 1 \mathrm{~J}$ 1,1: „Autor Listu odnosi się do logos [=Słowa - dop. thum.], które jest od zawsze (1 J 1,1a), a które w pełni objawiło się w historii we Wcieleniu (ww. 1de.2af), ale przede wszystkim przedstawia je jako Słowo przyjęte i wewnętrznie zinterioryzowane przez uczniów (ww. 1bc.3a)". 
składniowa całego wyrażenia. Łatwo bowiem dostrzec, że zakłóca ono szyk zdania. Według R.E. Browna autor stosuje je na zasadzie wtrącenia ${ }^{41}$. Tymczasem równie dobrze można dostrzec tu dosyć rzadką konstrukcję o charakterze anakolutycznym ${ }^{42}$, określaną jako casus pendens, tyle że wówczas wyrażenie to powinno rozpoczynać werset drugi: „A w odniesieniu do Słowa, które jest Życiem: Życie zostało objawione [...]". Na skutek takiego zabiegu zdanie to łączy się z dalszą częścią proklamowanego świadectwa (,życie wieczne, które było u Ojca”), po czym kolejny raz powracają czasowniki znane $\mathrm{z}$ wersetu pierwszego wraz z zaimkiem ho: „to, co widzieliśmy (heōrakamen) i słyszeliśmy (akēkoamen), proklamujemy (apangellomen) wam" $(1,3)$. F. Mickiewicz wykazuje w swojej monografii o świadkach Jezusa, że w tekście $1 \mathrm{~J}$ 1,1-3 są widoczne reminiscencje apostolskiego sposobu składania świadectwa popaschalnego, znanego z Dz 4,2043. Piotr i Jan, stając przed Sanhedrynem po uzdrowieniu chromego (Dz 3,1-10) i proklamacji kerygmatu (Dz 3,15: „Zabiliście Dawcę życia, ale Bóg wskrzesił Go z martwych, czego my jesteśmy świadkami”), nie opowiadają faktów z życia i działalności Jezusa, ale ukazują siebie jako naocznych świadków Jego misji zbawczej, której punktem kulminacyjnym była śmierć i zmartwychwstanie: „My bowiem nie możemy nie mówić tego (ha), co zobaczyliśmy (eidamen) i usłyszeliśmy (ēkousamen)". W ten sposób apostołowie dają do zrozumienia, że ogłoszony wcześniej kerygmat jest całkowicie wiarygodny. Również autor Pierwszego Listu św. Jana w podobny sposób autoryzuje swoje świa-

${ }^{41}$ Brown, The Epistles, 163-164. Można też popatrzyć na tekst $1 \mathrm{~J}$ 1,1-3 przez pryzmat możliwości stosowania przez autora konkretnych technik retorycznych, np. amplifikacji przez akumulację. Takie podejście prezentuje Watson, „Amplification”, 99-123.

${ }^{42}$ Zob. więcej na temat tego typu konstrukcji w: Blass - Debrunner, Grammatica, 567-570.

${ }^{43}$ Mickiewicz, Świadkowie, 261. W odniesieniu do 1 J Y. Simoens pisze, że zastosowane formy perfectum czasownika ,widzieć” jest znane w czwartej Ewangelii jako sposób wyrażania wiary paschalnej. Simoens, Le tre Lettere, 61. 
dectwo, przez co adresaci otrzymują gwarancję, że to, co ma postać dyskursu teologicznego, wyrasta z konkretnego doświadczenia historycznego. Niezależnie od tego, kto prezentuje dzieło w jego ostatecznym kształcie, ma on dostęp do ziemskiego Jezusa ( $\mathrm{w}$ danym momencie lub w przeszłości, być może na drodze przekazu kogoś innego), a jednocześnie posiada głębokie poznanie tajemnicy zbawczego działania Boga ${ }^{44}$.

\section{Podsumowanie}

Powyższe analizy leksykalne dowodzą, że mówiąc o naturze świadectwa w Pierwszym Liście św. Jana, można mu przyporządkować ideę anamnesis, którą w XX w. najpierw wypracował $\mathrm{P}$. Bonnard, a następnie rozwinął M. Eliade. Według tych autorów anamnesis w Nowym Testamencie nie polega jedynie na wiernym przywoływaniu z pamięci przeszłych wydarzeń historycznych (szczególnie Paschy Chrystusa). Jest ona raczej traktowaniem faktów jako „źródła teraźniejszości”. Z tego powodu w Kościele popaschalnym, pod wpływem działania Ducha Świętego, rozpoczął się proces akomodacji i aktualizacji przesłania wynikającego z paschalnego wypełnienia się historii w Jezusie Chrystusie ${ }^{45}$. Posługując się kategoriami żydowskiego myśliciela A.J. Heschela, który rozróżnia dwa źródła myślenia religijnego, „pamięć (tradycję)” oraz „osobiste wejrzenie”, można w Pierwszym Liście św. Jana odkryć semicki sposób podejścia do życia: „musimy polegać na pamięci, a z drugiej strony dążyć do nowych wejrzeń. Dowi a dujemy si ę dzięki tradycji, lecz także r o z u m i e m y dzięki własnym poszukiwaniom" ${ }^{46}$. To „osobiste wejrzenie” jest w życiu chrześcijanina wsparte

${ }^{44}$ Por. Fossati, Lettere di Giovanni, 37.

${ }^{45}$ Syntetycznie rozwój tej idei prezentuje Witczyk, Jezus i Ewangelie, 472 .

${ }^{46}$ Heschel, Bóg szukający człowieka, 38. 
światłem Ducha Świętego, który pozwala patrzeć na historię jako na arenę zbawczego działania Boga.

Co zatem ma na myśli autor Pierwszego Listu św. Jana, gdy przedstawia siebie jako świadka, a swoje pismo - jako świadectwo? Owocem jego pracy jest świadectwo teologiczne. Historia ziemskiego Jezusa w Pierwszym Liście św. Jana nie wyraża się bowiem w kategoriach historyczno-krytycznych, ale teologicznych ${ }^{47}$. U podstaw tego świadectwa znajduje się historiozbawczy przekaz naocznych świadków ${ }^{48}$. Nowe okoliczności egzystencjalne, w których znaleźli się adresaci, zmusiły autora $1 \mathrm{~J}$ do głębokiej refleksji teologicznej nad tym przekazem i prezentacji nowej wykładni, adekwatnej do potrzeb wspólnoty. Niemniej jest to świadectwo posiadające najwyższy autorytet.

\section{Bibliografia}

Beutler J., Das Johannesevangelium (Freiburg - Basel - Wien 2013).

Blass F. - Debrunner A., Grammatica del greco del Nuovo Testamento (ISBSup 2; Brescia ${ }^{2}$ 1997).

Brown R.E., The Epistles of John (AB 30; New York 1982).

Campbell C.R., Verbal Aspect, the Indicative Mood, and Narrative. Soundings in the Greek of the New Testament (SBG 13; New York 2007).

Dalbesio A., Quello che abbiamo udito e veduto. L'esperienza cristiana nella Prima Lettera di Giovanni (SRB 22; Bologna 1990).

${ }^{47}$ Można tu widzieć to, co G. Segalla określa mianem ,,memoria su Gesù" (pamiątka [pamięć] o Jezusie). Jest ona niejako owocem ciągłej re-aktualizacji i interpretacji ,pamiątki (pamięci) Jezusa” (memoria di Gesù). G. Segalla określa Pierwszy List św. Jana jako tekst z kategorii „pamiątki (pamięci) krytyczno-dyskursywnej” o charakterze teologicznym, który obejmuje ,mocne świadectwo o Jezusie ziemskim” a jednocześnie stanowi ,wyblakłą pamiątkę (pamięć) historyczną”. Segalla, Teologia biblica, 506-510.

${ }^{48}$ Por. Mickiewicz, Świadkowie, 260. 
Fanning B.M., Verbal Aspect in New Testament Greek (Oxford 1990).

Fossati M., Lettere di Giovanni, Lettera di Giuda (NVBTA 55; Milano 2012).

Griffith T., Keep Yourselves from Idols. A New Look at 1 John (JSNTSup 233; Sheffield 2002).

Heschel A.J., Bóg szukajacy człowieka. Podstawy filozofii judaizmu (Kraków 2007).

Jaromin J., „Chrystologia”, Teologia Nowego Testamentu. II.

Dzieło Janowe (red. M. Rosik) (BiBib; Wrocław 2008) 3981.

Klauck H.-J., Lettere di Giovanni (CPNT 22; Brescia 2013).

Mędala S., Ewangelia wedtug świętego Jana, rozdziały 1-12 (NKB NT IV/1, Częstochowa 2010).

Michaelis W., „horaō, theaomai ktl.”, Theological Dictionary of the New Testament (red. G. Kittel - G. Friedrich) (Grand Rapids 1964-1976) V, 315-381.

Mickiewicz F., Świadkowie zbawczego posłannictwa oraz mesjańskiej i boskiej godności Jezusa w pismach św. Łukasza $i$ św. Jana (Ząbki 2003).

Naselli A.D., „A Brief Introduction to Verbal Aspect in New Testament Greek", Detroit Baptist Seminary Journal 12 (2007) 17-28.

Painter J., First, Second and Third John (SP 18; Collegeville, MN 2002).

Passarella G., La dinamica del «Logos». La Parola in Giovanni per la vita e la missione della Chiesa (SRBib; Assisi 2011). Podeszwa P., Paschalna pamięć o Jezusie. Studium egzegetyczno-teologiczne wyrażenia hē martyria Iēsou w Apokalipsie św. Jana (UAM SiM 142; Poznań 2011).

Porter S.E., Verbal Aspect in the Greek of the New Testament with Reference to Tense and Mood (SBG 1; New York 1989).

Scott J.J., Jewish Backgrounds of the New Testament (Grand Rapids, MI ${ }^{9} 2007$ ).

Segalla G., Teologia biblica del Nuovo Testamento. Tra memoria escatologica di Gesù e promessa del futuro regno di Dio (Logos CSB 8/2; Torino 2006). 
Sikora A.R., ,Zobaczyt i uwierzyt” (J 20,8). Droga wiary umiłowanego ucznia Jezusa w ujęciu egzegezy teologicznej (Poznań 2012).

Simoens Y., Le tre Lettere di Giovanni. Credere per amare (Bologna 2012).

Sproston W.E., „Witness to what was ap'archēs: 1 John's Contribution to our Knowledge of Tradition in the Fourth Gospel", Journal for the Study of the New Testament 48 (1992) 43-65.

Stowers S.K., Letter Writing in Greco-Roman Antiquity (LEC 5; Philadelphia 1986).

Strathmann H., „martys ktl.”, Grande lessico del Nuovo Testamento (red. G. Kittel - G. Friedrich) (Brescia 1967) VI, 1269-1372.

Watson D.F., „Amplification Techniques in 1 John: The Interaction of Rhetorical Style and Invention", Journal for the Study of the New Testament 51 (1993) 99-123.

Witczyk H., Jezus i Ewangelie w ogniu dyskusji. Od H. Reimarusa do T. Polaka (BVV 2; Kielce 2011).

Wróbel M.S., Antyjudaizm a Ewangelia wedtug św. Jana (Lublin 2005).

Ks. Piotr Kot

ul. Jana Pawta II nr 1

59-220 Legnica

father.kefa@gmail.com

Ks. Piotr Kот, kapłan diecezji legnickiej, doktor teologii biblijnej Katolickiego Uniwersytetu Lubelskiego Jana Pawła II, licencjat nauk biblijnych Papieskiego Instytutu Biblijnego w Rzymie, licencjat teologii patrystycznej KUL, rektor WSD w Legnicy, adiunkt Katedry Egzegezy Nowego Testamentu w Instytucie Nauk Biblijnych Papieskiego Wydziału Teologicznego we Wrocławiu, wykładowca egzegezy Nowego Testamentu w WSD w Legnicy oraz języków semickich w Studium Języków Biblijnych we Wrocławiu, autor książek: Szkice biblijne. W namiocie Stowa (Wrocław 2010), Targumy a Pierwszy List Jana 
(Warszawa 2010), Wspótpracownicy Stwórcy (Włocławek 2011) oraz Radości i smutki świętego Józefa. Motywy biblijne Ewangelii Dzieciństwa wedtug Michała Willmanna (Legnica 2012). 
